University of Nebraska - Lincoln

DigitalCommons@University of Nebraska - Lincoln

USDA Forest Service / UNL Faculty Publications U.S. Department of Agriculture: Forest Service -National Agroforestry Center

2005

\title{
A retrospective analysis of known and potential risks associated with exotic toadflax-feeding insects
}

Sharlene E. Sing

U.S. Forest Service

Robert K.D. Peterson

Montana State University, bpeterson@montana.edu

David K. Weaver

Montana State University, weaver@montana.edu

Richard W. Hansen

Ft. Collins

George P. Markin

U.S. Forest Service

Follow this and additional works at: https://digitalcommons.unl.edu/usdafsfacpub

Part of the Forest Sciences Commons

Sing, Sharlene E.; Peterson, Robert K.D.; Weaver, David K.; Hansen, Richard W.; and Markin, George P., "A retrospective analysis of known and potential risks associated with exotic toadflax-feeding insects" (2005). USDA Forest Service / UNL Faculty Publications. 91.

https://digitalcommons.unl.edu/usdafsfacpub/91

This Article is brought to you for free and open access by the U.S. Department of Agriculture: Forest Service -National Agroforestry Center at DigitalCommons@University of Nebraska - Lincoln. It has been accepted for inclusion in USDA Forest Service / UNL Faculty Publications by an authorized administrator of DigitalCommons@University of Nebraska - Lincoln. 


\title{
A retrospective analysis of known and potential risks associated with exotic toadflax-feeding insects
}

\author{
Sharlene E. Sing ${ }^{\mathrm{a}, *}$, Robert K.D. Peterson ${ }^{\mathrm{b}}$, David K. Weaver ${ }^{\mathrm{b}}$, \\ Richard W. Hansen ${ }^{\text {c }}$, George P. Markin ${ }^{\text {a }}$ \\ ${ }^{a}$ U.S. Forest Service, Rocky Mountain Research Station, 1648 S. 7 th Avenue, Bozeman, MT 59717, USA \\ ${ }^{\mathrm{b}}$ Department of Land Resources and Environmental Sciences, Montana State University, Bozeman, MT, USA \\ ${ }^{\mathrm{c}}$ USDA-APHIS-PPQ, Center for Plant Health Science and Technology, Ft. Collins, CO, USA
}

Received 27 August 2004; accepted 18 August 2005

Available online 5 October 2005

\begin{abstract}
To date, eight exotic toadflax-feeding insect species have been accidentally or intentionally introduced to North America. Reports on their establishment and impact have been recorded for more than 60 years. Environmental risks linked to biological control of toadflax were identified in terms of host resources and undesirable impacts on the target species through the critical review of this record. Data gaps revealed during this retrospective analysis are addressed through suggestions for future research and associated experimental methodologies. Known and potential impacts of toadflax-feeding insects on both invasive toadflax and non-target species are examined. Recent programmatic demands for demonstrated agent efficacy and stringent host selectivity during the prerelease screening process clearly illustrate that classical biological control of invasive toadflax in North America is progressing beyond the so-called lottery approach.
\end{abstract}

(C) 2005 Elsevier Inc. All rights reserved.

Keywords: Toadflax; Biological control; Invasive weeds; Non-target effects; Environmental risk

\section{Introduction}

Prerelease screening that evaluates biocontrol agent performance, in terms of both efficacy and agent behavior (Arnett and Louda, 2002; Heard, 1999; Marohasy, 1998), should reduce potential risks associated with the agent when the agent is approved for release (Baars, 2000; Louda, 1998; Schaffner, 2001). Problems with the prerelease screening process for candidate agents, aside from the emphasis on detecting non-target impacts at the expense of evaluating efficacy (Kluge, 2000), arise from a multitude of methodological issues that compromise the value of host selectivity testing (Gassmann and Louda, 2001). Experimental methods used in prerelease screening have been crit-

\footnotetext{
* Corresponding author.

E-mail address: ssing@fs.fed.us (S.E. Sing).
}

icized for their lack of biological relevance (Withers, 1999), thereby failing as adequate indicators of potential agent performance in the release environment (Harris and McEvoy, 1995). Furthermore, unresolved taxonomic issues related to both the candidate agents and their targets have led to the approval of ineffective or inappropriate agents (Crawley, 1989; Myers and Bazely, 2003; Thomas and Willis, 1998). Because prerelease screening tests are so narrowly focused on reducing the potential risk of non-target impacts, risks associated with an incomplete knowledge of agent's potential performance in the treated ecosystem are significantly increased (Howarth, 2000).

Risks associated with the introduction of exotic weed biocontrol agents fall under two broad categories: (1) when the agent causes unintended and deleterious impacts to non-target species, and (2) when the agent fails to reduce populations of, or causes undesired impacts on, the target weed. Non-target impacts stem primarily from taxonomic 
uncertainty with regard to the target weed and the unknown degree of relatedness it shares, in terms of host acceptance and suitability, with closely related native, invasive or non-native ornamental relatives (van Klinken, 2000). Apart from the obvious undesired outcome of being ineffective, weed biocontrol agents may actually enhance weed fitness through inadequate herbivory or other ecological activities. Examples of herbivore-associated undesired impacts to weed species targeted for biological control may include: tolerance of herbivory (Strauss and Agrawal, 1999); compensatory growth responses to herbivory (Trumble et al., 1993); facilitation of sexual reproduction through pollination (Barthell et al., 2001; Goulson and Derwent, 2004); production of allelopathic exudates in response to herbivory (Callaway et al., 1999; Thelen et al., 2005); and semiochemical signaling to herbivore natural enemies (Paré and Tumlinson, 1999).

Efficacious biocontrol agent(s) have been successfully identified, screened, approved, and released against a number of exotic weed species targeted in long-term classical biological control programs (Coombs et al., 2004; Crawley, 1989; Mason and Huber, 2002; Story, 1992). Unfortunately, many agents have been released with little or no documentation of impact on target weed populations (Crawley, 1989; Kluge, 2000; McEvoy and Coombs, 1999; Syrett et al., 2000). At the same time, examples of non-target impacts have been widely publicized (Follett and Duan, 2000; Howarth, 1991; Louda et al., 1997; Pearson and Callaway, 2003; Simberloff and Stiling, 1996; Wajnberg et al., 2001). The resulting concerns over biological control safety necessitate new and more careful approaches to prerelease testing. Retrospective assessments of weed biological control can function as an exercise in accountability by consolidating and synthesizing all known information on agent interactions with target and non-target species, providing a systematic basis for identifying significant data gaps, particularly those concerning non-target impacts, and can be useful in improving specific aspects of future biocontrol enterprises (Gassmann and Louda, 2001; Hopper, 2001).

Dalmatian toadflax, Linaria dalmatica (L.) Miller, and yellow toadflax, L. vulgaris (Scrophulariaceae), are shortlived perennial herbs of Eurasian origin (Alex, 1962; Saner et al., 1995; Vujnovic and Wein, 1997). Dalmatian and yellow toadflax are widely distributed throughout North America. Between the two species, invasive toadflax populations occur in all US states except Hawaii (USDA-NRCS, 2004) and all Canadian provinces (Saner et al., 1995; Vujnovic and Wein, 1997). Three toadflax-feeding insect species are thought to have been adventitiously introduced on horticultural specimens of these weeds: the flower-feeding beetle, Brachypterolus pulicarius (L.) (Coleoptera: Kateridae), and two seed-capsule feeding weevils, Rhinusa (formerly Gymnetron) antirrhini Paykull, and R. neta Germar (Coleoptera: Curculionidae) (Smith, 1959). Classical biological control of exotic toadflax in North America was first initiated in the 1960s with the intentional introduction of five agents following host-specificity screening. These were: a foliar-feeding moth, Calophasia lunula Hufnagel (Lepidoptera: Noctuidae) (introduced in 1965); two rootboring moths, Eteobalea serratella Treitschke and E. intermediella Riedl (Lepidoptera: Cosmopterigidae) (1995); a root-galling weevil, Rhinusa linariae Panzer (Coleoptera: Curculionidae) (1995); and a stem-mining weevil, Mecinus janthinus Germar (Coleoptera: Curculionidae) (1995) (DeClerck-Floate and Harris, 2002; Harris, 1984; Harris and Carder, 1971; McClay and Declerck-Floate, 2002).

Progress in the biological control of exotic toadflax in North America has been reported for more than 50 years (Smith, 1956). This record provides an excellent opportunity for retrospective analysis as a relevant and informative case study for identifying potential risks and benefits of biological control (Hopper, 2001; Louda et al., 2003). The following evaluation serves first as a review of documented examples that confirm existing problems in the prerelease screening of toadflax biocontrol agents. In addition, this critique examines how new methods of investigation may potentially enhance the prerelease evaluation process by identifying potential undesired impacts on the target species. Specialized spatial and ecological statistical methods are discussed as analyses that could be performed to enhance risk/benefit assessments for situations where there is some indication that biocontrol benefits might be confounded by ecological risks associated with the introduction of a candidate agent.

\subsection{Known and potential risks: host resources}

\subsubsection{Identity crisis: target weed taxonomic and genotypic uncertainty}

Consensus on the taxonomic designation of invasive, exotic toadflaxes has been elusive. Dalmatian toadflax has been treated both as a subspecies of broomleaf toadflax, (Linaria genistifolia (L.) P. Mill.), L. genistifolia (L.) Miller ssp. dalmatica (L.) Maire \& Petitmengin (Chater et al., 1972), and as a species entity (L. dalmatica (L.) Miller) completely separate but closely related to L. genistifolia (Davis, 1978; Hartl, 1974; Sutton, 1988). Canadian weed biocontrol researchers consider these two species so closely related as to use the common name "broad-leaved Dalmatian toadflax" to denote L. dalmatica (L.) Mill., and "narrow-leaved Dalmatian toadflax" for L. genistifolia (Harris and DeClerck-Floate, 2003).

The USDA, NRCS PLANTS database currently lists the species Linaria dalmatica (L.) P. Mill. with two subspecies: spp. dalmatica and spp. macedonica (Griseb.) D.A. Sutton, as separate from Linaria genistifolia, a species with one variety, var. genistifolia (USDA-NRCS, 2004). Alex (1962) similarly distinguishes two varieties (rather than subspecies) of L. dalmatica, var. dalmatica and var. macedonica, through a list of morphological characters. Alex (1962) believed that $L$. dalmatica var. macedonica had a very restricted indigenous range and therefore stated that North American horticultural trade and botanical collection references to this variety were incorrect. Today, the range of 
L. dalmatica ssp. macedonica in the United States is limited to five states: Indiana, Iowa, Massachusetts, New Hampshire, Oregon, and Washington (USDA-NRCS, 2004). However closely they may be related, these two target weed species (i.e., L. dalmatica and L. genistifolia) are thought to be distinct enough to differentially influence biocontrol agent efficacy (Harris and DeClerck-Floate, 2003; Jeanneret and Schroeder, 1991; Saner et al., 1990; Smith, 1959). Final reports summarizing the results of host selectivity testing of approved biocontrol agents, including $R$. anitrrhini (Groppe, 1992), E. intermediella and E. serratella (Saner et al., 1990), and M. janthinus (Jeanneret and Schroeder, 1991) show that in prerelease screening tests, the Canadian biotype of L. dalmatica was not clearly identified as broad- or narrow-leaved Dalmatian toadflax, but it was treated as a separate entity from L. genistifolia.

Taxonomic ambiguity of the target weed can be further complicated if conditions favor the evolution of novel genotypes. The introduction of exotic plant species through multiple events, times, and locations, especially those species with extensive home ranges, can lead to the evolution of novel genotypes in the adopted environment (Ellstrand and Schierenbeck, 2000; Müller-Schärer and Steinger, 2004). Dalmatian and yellow toadflax owe their wide distribution and long history of establishment in North America to repeated introductions by settlers who valued both species as garden ornamentals and as key ingredients in medicinal and textile-dying preparations (Lajeunesse, 1999).

Hybridization between previously isolated species or subspecies can also produce novel genotypes (e.g., Gaskin and Schaal, 2002). Both $L$. dalmatica and L. vulgaris are self-incompatible (Docherty, 1982; Saner et al., 1995; Vujnovic and Wein, 1997). The frequency of hybridization within the Linaria is thought to be fairly high, although the occurrence of hybridization between $L$. dalmatica and $L$. vulgaris has not been recorded (Bruun, 1937; Janko, 1964; Olsson, 1974, 1975). O'Hanlon et al. (1999) suggest that in cases where genetic diversity in invasive weeds has been confirmed, management tactics, including biological control, should be evaluated for efficacy across the full range of target weed diversity. Furthermore, classical biological control of exotic weeds can be significantly confounded when the target species has evolved into a hybrid complex that has become critically dissimilar to hosts in the native range from which candidate agents would be collected, exemplified by biocontrol of Lantana camara in South Africa (Baars, 2000).

\subsubsection{Taxonomic uncertainty: native North American Scrophulariaceae}

Recent taxonomic revisions within the figwort family, Scrophulariaceae (Albach et al., 2005; Olmstead et al., 2001), indicated that Old World Linaria spp., such as Dalmatian and yellow toadflax, are more closely related to New World Sairocarpus (formerly New World Antirrhinum) (ITIS, 2004), Maurandya, and Penstemon spp. than previously assumed (Hansen and Gassmann, 2002). The same revision reclassified three former New World Linaria and determined that they belonged in their own genus, Nuttallanthus D.A. Sutton: N. canadensis (L.) , N. floridanus (Chapman), and N. texanus (Scheele) (BONAP, 1996; ITIS, 2004). Taxonomic ambiguity at the time of initial prerelease host-specificity screening for the majority of established toadflax agents therefore resulted in the omission of key related native North American species from evaluation. Post-release host specificity tests conducted to address the potential for M. janthinus (Gassmann, 2001; Hansen and Gassmann, 2002), C. lunula (R.W. Hansen, unpublished data), and R. neta (Gassmann, 2001) to attack non-target native North American Scrophulariaceae revealed that although non-status native plant species were found to be susceptible to attack, no native threatened or endangered figworts were at risk.

Results of choice tests with $M$. janthinus conducted to assess the agent's potential to attack North American Scrophulariaceae indicated that one native North American species with a distribution limited to California (USDA-NRCS, 2004), Sairocarpus virga (Gray) D.A. Sutton, as being fully capable of supporting larval development of $M$. janthinus, although significantly fewer progeny were produced on this non-target host than on Dalmatian toadflax (Hansen and Gassmann, 2002). Under a conservative, Tier I risk assessment, the effect threshold or unacceptable level of risk for host-switching would be the successful production of agent progeny on any non-target plant species. A risk characterization of the potential for $M$. janthinus to impact $S$. virga beyond the acceptable critical effects threshold would require filling a number of data gaps (= ecological criteria sensu Arnett and Louda, 2002). This process might include determining: the phenologies of Dalmatian toadflax, S. virga, and M. janthinus under local environmental influences; the relative densities and spatial distribution of the two host plant species; $M$. janthinus disperal, feeding, and oviposition patterns under local conditions; and the impact of stochastic environmental perturbations that may potentially influence $M$. janthinus host use and acceptance patterns (i.e., wildfire, spray programs, atypical climatic events). Because $M$. janthinus remains the best available agent for Dalmatian toadflax biocontrol and this invasive weed is of significant concern in California (CDFA, 2005; Sonder and Talbert, 1973), policy makers might decide to conduct a risk assessment constrained by a less conservative host-switching effects threshold. In that case, further investigation would have to be undertaken to determine if $M$. janthinus acceptance of $S$. virga for oviposition is novel, if the agent demonstrates host preference, or if agent exploitation of the non-target or target host is influenced by the relative abundance or spatial distribution of either species.

According to the Jepson Flora Project (http:// ucjeps.bereley.ecu/jepson_flora_project.html), an online resource for Californian floristic evaluations, $L$. dalmatica and $S$. virga have known overlapping distributions, in the context of being equally accessible to mobile $M$. janthinus 
adults, in at least two California floristic provinces. When two or more acceptable host species are present, herbivore preference for one species over another (electivity sensu Singer, 2000) can be evaluated by determining if the number of individuals of one plant species attacked by the herbivore species is proportionate to its relative density (Cock, 1978), by adapting the methods outlined in Murdock (1969).

\subsubsection{Alternative host issues: related non-native weedy and ornamental species}

Host-selectivity screening for the majority of toadflax biological control agents has included individuals of the target species drawn from both the native and adopted range (Gassmann and Paetel, 1998; Groppe, 1992; Jeanneret and Schroeder, 1991; Saner et al., 1990). Increased genetic variability within exotic invasive plant populations, especially those species with domesticated (i.e., ornamental) and wild counterparts, may confound herbivore host selection (Chen and Welter, 2003). Several non-native species within the genus Linaria are now considered to be naturalized, according to the USDA 1982 National List of Plant Names (Jeanneret and Schroeder, 1991), and frequently appear as test species in host-selectivity evaluations of candidate toadflax biocontrol agents. One of those, dwarf snapdragon, Chaenorrhinum minus (L.) Lange $(=L$. minor (L.) Lange), is an annual that has received minor attention in the host-screening process for toadflax biological control agents. This is because most agents are thought to be predominantly associated with short-lived perennials, although this degree of host longevity is not required for every toadflax biocontrol agent species. Additionally, the cost of attack on naturalized, non-native ornamental Linaria was deemed to be acceptable collateral damage, compared to the benefits to be garnered from the effective management of yellow and Dalmatian toadflax: "reduction in the abundance of roadside toadflax flowers is a price that must be paid for control by biological or other means" (Saner et al., 1990, p. 19; Jeanneret and Schroeder, 1992, p. 17).

Host specificity of $R$. neta (Rhine Valley origin) evaluated through a multiple-choice oviposition and larval development experiment indicated that the greatest number of pupae and adults were produced on the native range host, $L$. vulgaris (EU origin), followed by the annual species, Chaenorrhinum minus (Gassmann and Paetel, 1998). Chaenorrhinum minus was introduced and disseminated throughout North America in ballast material that was in turn used as a foundation for transcontinental railway beds (Arnold, 1981, 1991; Widrlechner, 1982). Due to its ubiquitous distribution along transportation corridors, a species such as $C$. minus could provide a means for agents to come into contact with potential native non-target hosts thought to be secure from attack by toadflax biocontrol agents due to their allopatric distribution with $L$. dalmatica or $L$. vulgaris. The potential role of such "bridge" alternative host species in non-target attack probably merits consideration in the preparation of comprehensive risk assessments in weed biological control (Louda et al., 2003; Pemberton, 1985).

Another example of non-target feeding by a toadflax biocontrol agent on naturalized non-native, related ornamental species involves the larval stage of the toadflax defoliating moth $C$. lunula, which readily feeds (Karny, 1963) and completes development (Harris, 1963) on three ornamental species: common snapdragon or Antirrhinum majus, Cymbalaria muralis, and Linaria maroccana. Two of these, A. majus and L. maroccana, have become "weedy" escaped ornamentals in several US states, including California (USDA-NRCS, 2004). In this context, both the target weed(s) and a common ornamental, A. majus, could function as alternative hosts by sustaining localized populations of $C$. lunula within the geographic range of a potential native non-target host species, $S$. virga.

An exposure assessment, taking into consideration the following temporal and spatial factors, would clarify the risks of host-switching by yielding a "dose response" for $C$. lunula encounters with all three plant species: relative abundance and frequency of spatial and temporal co-occurrence of the target host(s), the "weedy" ornamental non-target host and the putative native non-target host, and degree of phenotypic synchrony/asynchrony between the agent and target/non-target hosts. A risk assessment of toadflax biological control for California would need to weigh the risks of agent host switching, especially confounded by the frequency that common snapdragon is used and escapes as an ornamental plant, against the need for effective Dalmatian toadflax biological control. Host-screening of S. virga for $C$. lunula host acceptance and host suitability demonstrated that although $C$. lunula completed development on $S$. virga in the lab, survival, and "performance" (e.g., development time, pupal weight) were significantly less than that on $L$. dalmatica or L. vulgaris (Hansen, unpublished data). Given the continuous distribution of $L$. dalmatica and $L$. linaria throughout much of the United States and Canada, complete geographic separation of invasive and native or introduced ornamental toadflaxes seems unlikely.

\subsubsection{Biotypes or host-race considerations: toadflax biocontrol agents}

Geographical separation can result in populations of herbivorous insect species that preferentially exploit different host species, host races that arise as a manifestation of adaptive ecological differentiation. Host race has been characterized by genetic, behavioral, or combined genetic and behavioral differentiation (Craig et al., 1993, 2000; Diehl and Bush, 1984; Drès and Mallet, 2002; Hopper et al., 1993; Narang et al., 1993). Drès and Mallet (2002) point out that the definition of "host race" is elusive, and that conferring the status of "host race" is a subjective categorization of "one of a number of intermediates in the continuum between polymorphisms and full species."

The steppes of southeastern Europe and southwestern Asia form the native range of Linaria vulgaris (Saner et al., 1995), while $L$. dalmatica is thought to originate in the 
Mediterranean region, reportedly from Yugoslavia to Iran (Vujnovic and Wein, 1997). The host race argument has been used to support the petition and subsequent release of host specific biotypes of two toadflax agents, Rhinusa antirrhini and Brachypterolus pulicarius, and a number of studies have investigated the possibility that geographically disparate populations of certain toadflax biocontrol species occurring on both $L$. dalmatica and $L$. vulgaris may have evolved distinct host races in response to the locally prevalent Linaria species (Groppe, 1992; Harris and Gassmann, 2004; Hering, 2002; Nowierski, 1995; Smith, 1959).

The adventively introduced agent Rhinusa antirrhini, reported as widely distributed on $L$. vulgaris and the narrow-leaved form of $L$. dalmatica, was thought to be incapable of successful reproduction on broad-leaved $L$. dalmatica (Smith, 1959). Because qualitative assessments attributed a reduction in L. vulgaris seed production to $R$. antirrhini (Darwent et al., 1975; Harris, 1961), foreign exploration was undertaken to identify collectable populations of $L$. dalmatica-adapted $R$. antirrhini in the species' native range. Weevils collected from Dalmatian toadflax in Yugoslavia (Groppe, 1992) were initially released in Canada in 1993 (DeClerck-Floate and Harris, 2002). The $L$. dalmatica host race of $R$. antirrhini was released in the US in 1996 following an environmental assessment with a finding of no significant impact (Nowierski and Hennessey, 1995).

McClay and Declerck-Floate (2002) suggest that a reduction in the efficacy of the yellow toadflax host race of Rhinusa antirrhini may be attributed to a European parasitoid, first reported in the same year as the initial US release of the L. dalmatica host race of $R$. antirrhini (Volenberg and Krauth, 1996). Furthermore, Harris and Gassmann (2004) contend that $L$. dalmatica-adapted $R$. antirrhini are not a host race but in fact a separate, unnamed sibling species of Rhinusa as evidenced by their significantly different mitochondrial DNA profiles. Hopper et al. (1993) discuss how a genetic diagnosis can reveal that an assumed intraspecific variation among insect species strains, for example, the development of host specificity for different plants, is actually a case of genetic variation among sibling species. Permitting a new species of weed biocontrol agent to bypass intensive pre-release screening because it was assumed to be a host race of a previously intentionally or adventively introduced species can create the potential for a number of negative ecological and regulatory repercussions.

Field performance of a second insect species, Brachypterolus pulicarius, was thought to support the notion that host affinity evolving toward separate host races on Linaria vulgaris and $L$. dalmatica had occurred in this species (Grubb et al., 2002). Smith (1959) reported that B. pulicarius was found only on L. vulgaris hosts growing in a garden of potential Scrophulariaceae hosts at the Canadian Department of Agriculture Entomology Laboratory in Belleville, Ontario. The same account also mentions that this insect species had also been collected from broad- leaved Dalmatian toadflax at two locations in Saskatchewan (Smith, 1959). In 1992, B. pulicarius collected from $L$. dalmatica in Kamloops, B.C. were released on Dalmatian toadflax at three sites in Montana, then confirmed as established the following year (Nowierski, 1995). Amplified Fragment Length Polymorphism (AFLP) analysis of $B$. pulicarius populations collected throughout the native and adopted ranges found no evidence to suggest that genetic variability between the host races had advanced to the point of speciation (Hering, 2002).

The concerted campaign to release Dalmatian toadflaxadapted B. pulicarius and $R$. antirrhini in North America exemplifies the "lottery approach" to biological control which may build unnecessary complexity and non-target risk into biocontrol systems (McEvoy and Coombs, 2000). Although B. pulicarius delays flowering and seed production in L. vulgaris (McClay, 1992), it has not truly changed the scope or prevalence of problems associated with this invasive weed (McClay and Declerck-Floate, 2002). If agent efficacy is modest for the ubiquitous, adventively introduced yellow toadflax host races of these two seed-targeting agents against $L$. vulgaris hosts producing an average of 5584 seeds/stem (Zilke and Coupland, 1954), how could an even equal impact be anticipated against Dalmatian toadflax, with an average seed production of 50,000 seeds/stem(Saner et al., 1995)? Both of these agents are seed-feeders with little or no potential to affect meaningful top-down control of the target weed (McEvoy and Coombs, 1999). Because the more recently introduced agent host races were not selected to improve host-herbivore climate matching, it seems fair to suggest that the past performance of the yellow toadflax host races of these agents should have figured more prominently in the decision to approve and release the $L$. dalmatica agent host races. Finally, aside from the marginal impact of these agents on the persistence of target weed populations, the decision to import Dalmatian toadflax host races of these two agents should have been reconsidered, based on Harris' (1961) description of the antagonistic interactions between B. pulicarius and $R$. antirrhini on $L$. vulgaris. This account presents a classic example of intra-guild predation (Rosenheim et al., 1995), with the two species competing for the same host resources, and their combined efforts thought to be additive, but below the level of seed destruction necessary to suppress populations of the weed (Harris, 1961).

\subsection{Known and potential undesired impacts on the target weed}

\subsubsection{Tolerance of herbivory}

In weed biological control, impact has largely been measured in terms of agent and host demography in isolation, rather than in concert (McClay, 1995; Syrett et al., 2000). This approach relies heavily on correlative rather than causal explanations for reductions in target weed populations (McEvoy and Coombs, 1999). Quantitative studies most frequently address units (i.e., above- or below-ground 
biomass, leaves, seedheads, etc.) of host consumption per time interval (Karny, 1963; McClay, 1995). To date, studies of toadflax biocontrol efficacy have only speculated on specific mechanisms involved in differential resource allocation to vegetative versus reproductive structures, extrapolating this to the population level (Carney, 2003; Grubb et al., 2002; Müller, 1989; Saner et al., 1990; Schierenbeck et al., 1994).

Experimental results confirm that biomass removal has little sustained impact on well-established infestations of $L$. vulgaris (Alberta Agriculture, 1988; Saner et al., 1995) or $L$. dalmatica (Robocker et al., 1972; Vujnovic and Wein, 1997). Weed species with dual modes of reproduction, including yellow and Dalmatian toadflax, are particularly resilient to simple biomass reduction (Lajeunesse, 1999).

Successful biological control of invasive weeds with herbivorous, host-specific insects is predicated on the assumption that insect-induced injury stresses the weeds sufficiently to cause critical reductions in individual fitness and thereby, weed populations. Plant primary physiological processes such as photosynthesis, stomatal conductance, transpiration, chlorophyll fluorescence, and respiration are crucial determinants of plant growth, yield, and fitness (Meyer, 2000, 1993). However, specific information on the physiological response of invasive weeds to insect herbivory, as a mechanistic explanation of agent efficacy, is relatively rare (but see Overholt et al., 2004; McConnell et al., 1995). Understanding plant physiological responses to select herbivory and tracking the impact of those responses on the weed's population and community dynamics could potentially provide a quantitative and systematic method for evaluating agent efficacy (Arntz et al., 1998).

Field studies conducted at sites where releases of the toadflax stem-mining weevil, $M$. janthinus, had previously established revealed that Dalmatian toadflax physiology was significantly altered in plants infested by the biological control agent, compared to uninfested neighboring plants (Peterson et al., 2005). In particular, photosynthesis and gas exchange traits such as stomatal conductance, intercellular $\mathrm{CO}_{2}$, and transpiration were significantly lower in infested compared to uninfested plants. These results suggest that measurable correlates of the status of primary metabolic functioning in Dalmatian toadflax are impacted by this biocontrol agent and may explain its efficacy in controlling the target weed (Carney, 2003; DeClerck-Floate and Miller, 2002; Jeanneret and Schroeder, 1992). In greenhouse and field evaluations, gas exchange variables were recorded on Dalmatian toadflax plants subjected to simulated defoliation by clipping or herbivory by $C$. lunula larvae, for comparison to untreated plants. Plants where $C$. lunula injury was simulated by clipping portions of leaves with scissors had no different response than those subjected to herbivore defoliation or left untreated. These results suggest that toadflax agents with a simple defoliation mode of action are unlikely to impact toadflax primary metabolism (i.e., photosynthesis, stomatal conductance, transpiration, and intercellular $\mathrm{CO}_{2}$ ). Larval defoliation by $C$. lunula reduced leaf area, but did not apparently impact the photosynthetic apparatus of remaining tissue. Although adult M. janthinus defoliated a much smaller leaf area per experimental plant than plants under attack by $C$. lunula larvae, a significant depression in primary physiological functioning could be linked to the disruption of xylem tissues by the feeding activities of larval $M$. janthinus. While primary physiological responses are not intended to be predictors of plant fitness, they can be used to assess physiological impairment that may lead to fitness loss. M. janthinus exerted the greater impact on $L$. dalmatica primary metabolic functioning and can be credited with reducing Dalmatian toadflax infestations at a number of western North American locations (S.E. Sing, pers. obs.; DeClerck-Floate and Harris, 2002); in spite of its wider distribution and longer tenure in North America, C. lunula has not had much of an impact on target weed populations (Nowierski, 2004).

Using similar methods to diagnose in situ plant primary physiological responses to herbivory by specific agents during the initial phases of the candidate screening process in the target weed's native range. This approach could potentially provide a quantitative and systematic method for evaluating agent efficacy. Because effective biological control of weeds generally depends more on compromising the competitive ability of the target species than on "killing" or "eating" populations to local extinction, objective, quantifiable indicators of agent-mediated physiological stress could have a useful role in identifying appropriate candidate agents.

\subsubsection{Compensatory responses to herbivory}

Gross biomass removal is the coarsest resolution of agent impact on a target weed. Attack on L. vulgaris by the root-mining larvae of the moth $E$. serratella increased vegetative growth, doubling the number of stems in host plants, although total biomass was not found to be significantly different when infested (attacked) and uninfested plants were compared (Saner and Müller-Schärer, 1994). However, assessments of root herbivory impact based solely on biomass reduction do not account for an indirect but major impact of root-feeding weed biological control agents: facilitation of pathogenic attack on the target weed through entry points created by herbivore activities such as feeding, oviposition or tunnelling (Caesar, 2000).

Dalmatian toadflax plants attacked by the ovary- and pollen-feeding beetle $B$. pulicarius were shorter in stature and also exhibited increased primary and secondary branching (Grubb et al., 2002). Brachypterolus pulicarius attack on yellow toadflax also resulted in auxiliary branching (Selleck et al., 1957) but with no attendant reduction in dry weight or root/shoot ratio (McClay, 1992). In general, results pertaining to toadflax's vegetative growth indicate that although there was an increase in the number of host stems or shoots in herbivore-exposed plants, total biomass was generally not altered. Analyzing this agent's impact from a community perspective suggests that because affected plants did not lose biomass or size, herbivory may 
have actually increased the target weed's competitive advantage, in terms of the limiting resource of space, at no apparent cost in moisture and nutrient capture.

\subsubsection{Herbivore-mediated impacts on weed sexual reproduction and self-defense}

Stand persistence, a measure of fitness at the population level in perennial weed species such as yellow toadflax with both sexual and asexual modes of reproduction, is attributed more to vegetative growth rather than sexual reproduction (Honnay and Bossuyt, 2005; Nadeau and King, 1991; Olejniczak, 2003; Rautiainen et al., 2004). Although individual plants may produce up to an estimated 33,000 seeds (Kock, 1966), yellow toadflax seedling establishment is constrained by low seed viability and high seed dormancy (Nadeau and King, 1991). Biocontrol agents focusing their attack on toadflax pollen and ovaries impact host fitness at the level of the individual by reducing the probability that the individual's genetic material will be carried on to subsequent generations through pollination (Arnold, 1982). Grubb et al. (2002) suggest that because $B$. pulicarius affects host reproductive allocation and seed production, and thereby opportunity and potential for propagule dispersal, it indirectly but significantly impacts the possibility for rapid adaptation due to uniparental constraint (Holsinger, 2000), which could result in local extinction (Honnay and Bossuyt, 2005).

The regulatory role of herbivory-induced volatile production in tri-trophic relations has been well-documented (Kessler and Baldwin, 2001; Turlings et al., 1995). Plant secondary metabolism involves the stress-induced activation of biochemical pathways thought to be driven by a longstanding co-evolution of the plant species with select biotic stressors. The purpose of elicited responses is to stem the continuation of further stress, and to limit or eliminate the impacts of existing stress to affected plants (Alborn et al., 1997; Röse et al., 1996; Paré and Tumlinson, 1997, 1998; Paré et al., 1998). The release of volatile compounds from plants attacked by biocontrol agents could doom agent effectiveness if the compounds served to attract predators that reduce agent fitness.

A portable volatile collection system was used to determine if the volatile signature differed in Dalmatian toadflax plants free of natural enemies or actively under attack by either M. janthinus or C. lunula at well-established release sites where agents were consistently present. Volatile compounds eluted from the sample filters were identified and quantified through GC-MS analysis, which determined the retention time and identity of specific plant compounds. Volatile peaks present at two retention times indicated the presence of differential amounts of two compounds-one, identified as junipene, was present only in uninfested Dalmatian toadflax (Fig. 1A) and the other, geranylacetone, was collected only from $M$. janthinus infested plants (Fig. 1B).

Junipene is an attractant component of floral and vegetative volatiles produced in plant species pollinated by night-active noctuid moths (Levin et al., 2001). Geranylace- tone is a wound-response "alarm" volatile that functions as an attractant to herbivore natural enemies (Boland et al., 1998). Calophasia lunula moths feed on toadflax nectar beginning at dusk and probably pollinate the flowers during the course of nocturnal feeding and egg-laying (Karny, 1963). Calophasia lunula larvae experience a high rate of parasitism at some North American biocontrol release sites (McClay and Hughes, 1995). These factors suggest that the degree of coevolution in this host-herbivore system may doom anthropogenic manipulation for weed population regulatory purposes (Mauricio and Rausher, 1997). Further evaluations will be necessary to conclusively determine that C. lunula facilitates pollination in its self-incompatible host species.

\section{Discussion}

A number of toadflax biocontrol agents have been approved and released in North America (Table 1), even though their fundamental host range (van Klinken, 2000; Nechols et al., 1992) includes native North American or common ornamental species. Host-specificity tests indicate that in general, the frequency and intensity of attacks on non-target hosts were lower, and the incidence of completed development through the entire reproductive cycle was low or rare. Also rates of development were generally protracted when compared to agent performance on target weed hosts. However, the case study of the musk thistle biocontrol agent Rhinocyllus conicus (Frölich) illustrates that indicators of non-target risk should not be discounted (Louda, 2000; Louda et al., 2005). Because prerelease tests indicated that $R$. conicus preferred Carduus spp. hosts and developed more slowly on Cirsium spp., the risk posed to native thistles was promoted as insignificant compared to the problem of invasive thistles (Zwölfer and Harris, 1984).

The decision to monitor plant species that had been identified as potential but not probable non-target hosts (Rees, 1977; Turner et al., 1987) was key to accurately characterizing $R$. concicus' realized or field host range (van Klinken, 2000). Increased monitoring, especially of potential but improbable non-target hosts (as indicated through prerelease host-selectivity testing), would accurately delineate the field host range of the current suite of toadflax biocontrol agents. Ideally, the parameterization of toadflax agents' field host range would include ecological evaluations of target and non-target host use based on the relative abundance, and temporal or spatial distribution patterns of co-occurring potential host species (McClay, 1995; Syrett et al., 2000).

The use of plant taxonomy in host-specificity testing succeeds or fails depending on the accuracy with which phylogenetic relationships are characterized (Futuyama, 1999). As a result of recent taxonomic revisions within the Scrophulariaceae, a number of native species have been identified as potential hosts to toadflax biocontrol species, a development that could not have been anticipated at the time that the majority of the agents were approved for 
A

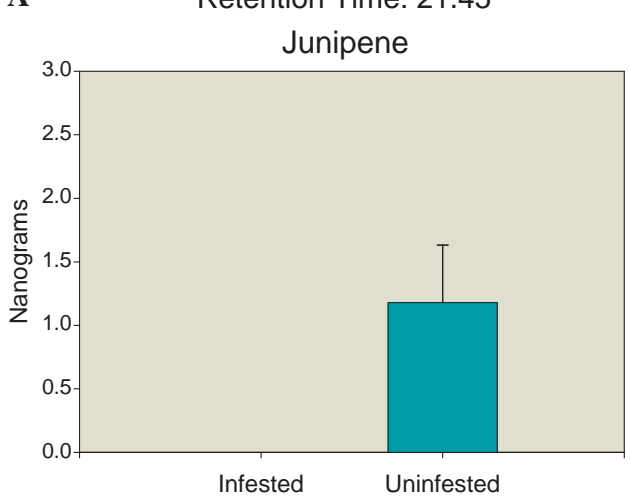

B

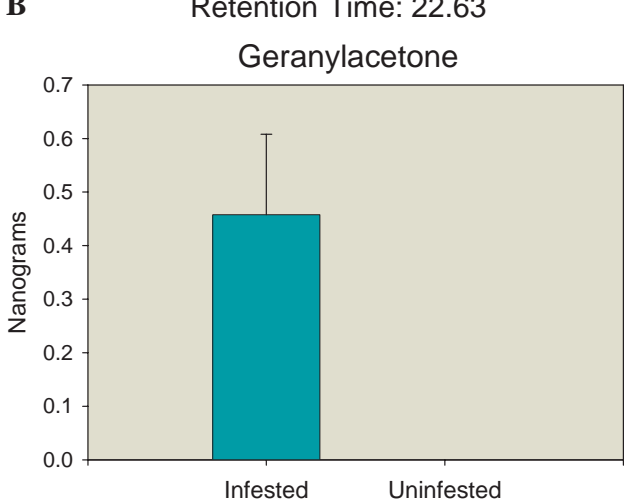

Fig. 1. Mean values for volatiles produced by L. dalmatica: (a) uninfested and (b) infested with larval Mecinus janthinus. (A) Junipene collected from uninfested Dalmatian toadflax; volatile absent in plants infested by larval Mecinus janthinus. (B) Geranylacetone collected from infested Dalmatian toadflax; volatile absent in plants free of larval Mecinus janthinus.

release in North America. However, the decision to evaluate the susceptibility of these recently identified native species to approved or adventively introduced agents
(Gassmann, 2001) exemplifies the proactive stance taken by toadflax biocontrol researchers to filling existing data gaps as they emerge.

Table 1

Exotic toadflax-feeding insect species released or reported in the U.S.

\begin{tabular}{|c|c|c|c|c|c|}
\hline Agent & $\begin{array}{l}\text { Mode of introduction } \\
\text { Date } \\
\text { Current distribution }\end{array}$ & Target host & Injurious stage(s) & Target organ(s) & $\begin{array}{l}\text { Impact on Target } \\
\text { US populations }{ }^{\mathrm{d}}\end{array}$ \\
\hline $\begin{array}{l}\text { Brachypterolus pulicarius } \\
\text { (Coleoptera: Kateridae) }\end{array}$ & $\begin{array}{l}\text { Accidental } \\
1919\end{array}$ & L. vulgaris & Adult & Shoots & Minimal \\
\hline L. vulgaris host race & Common & & Larvae & $\begin{array}{l}\text { Flowers } \\
\text { Seeds }\end{array}$ & Minimal \\
\hline $\begin{array}{l}\text { Brachypterolus pulicarius } \\
\text { (Coleoptera: Kateridae) }\end{array}$ & $\begin{array}{l}\text { Intentional } \\
1992\end{array}$ & L. dalmatica & Adult & Shoots & Minimal \\
\hline L. dalmatica host race & Limited & & Larvae & $\begin{array}{l}\text { Flowers } \\
\text { Seeds }\end{array}$ & Minimal \\
\hline $\begin{array}{l}\text { Rhinusa antirrhini } \\
\text { (Coleoptera: Curculionidae) }\end{array}$ & $\begin{array}{l}\text { Accidental } \\
1909\end{array}$ & L. vulgaris & Adult & Seeds & Minimal \\
\hline L. vulgaris host race & Common & & Larvae & Seeds & Minimal \\
\hline $\begin{array}{l}\text { Rhinusa antirrhini } \\
\text { (Coleoptera: Curculionidae) } \\
\text { L. dalmatica host race }\end{array}$ & $\begin{array}{l}\text { Intentional } \\
1996 \\
\text { Unknown }\end{array}$ & L. dalmatica & $\begin{array}{l}\text { Adult } \\
\text { Larvae }\end{array}$ & $\begin{array}{l}\text { Seeds } \\
\text { Seeds }\end{array}$ & $\begin{array}{l}\text { Unknown } \\
\text { Unknown }\end{array}$ \\
\hline $\begin{array}{l}\text { Calophasia lunula } \\
\text { (Lepidoptera: Noctuidae) }\end{array}$ & $\begin{array}{l}\text { Intentional } \\
\text { 1960’s } \\
\text { Common }\end{array}$ & $\begin{array}{l}\text { L. dalmatica } \\
\text { L. vulgaris }\end{array}$ & $\begin{array}{l}\text { Larvae } \\
\text { Larvae }\end{array}$ & $\begin{array}{l}\text { Foliage } \\
\text { Foliage }\end{array}$ & $\begin{array}{l}\text { Minimal } \\
\text { Minimal }\end{array}$ \\
\hline $\begin{array}{l}\text { Rhinusa linariae } \\
\text { (Coleoptera: Curculionidae) }\end{array}$ & $\begin{array}{l}\text { Intentional } \\
1996 \\
\text { Unknown }\end{array}$ & $\begin{array}{l}\text { L. dalmatica } \\
\text { L. vulgaris }\end{array}$ & $\begin{array}{l}\text { Adult } \\
\text { Larvae }\end{array}$ & $\begin{array}{l}\text { Shoots } \\
\text { Roots }\end{array}$ & $\begin{array}{l}\text { Unknown } \\
\text { Unknown }\end{array}$ \\
\hline $\begin{array}{l}\text { Eteobalea serratella } \\
\text { (Lepidoptera: Cosmopterygidae) }\end{array}$ & $\begin{array}{l}\text { Intentional } \\
1996 \\
\text { Unknown }\end{array}$ & L. vulgaris & Larvae & Roots & Unknown \\
\hline $\begin{array}{l}\text { Eteobalea intermediella } \\
\text { (Lepidoptera: Cosmopterygidae) }\end{array}$ & $\begin{array}{l}\text { Intentional } \\
1996 \\
\text { Unknown }\end{array}$ & $\begin{array}{l}\text { L. dalmatica } \\
\text { L. vulgaris }\end{array}$ & Larvae & Roots & Unknown \\
\hline $\begin{array}{l}\text { Mecinus janthinus } \\
\text { (Coleoptera: Curculionidae) }\end{array}$ & $\begin{array}{l}\text { Intentional } \\
1992 \\
\text { Limited }\end{array}$ & $\begin{array}{l}\text { L. dalmatica } \\
\text { L. vulgaris }\end{array}$ & $\begin{array}{l}\text { Adult } \\
\text { Larvae }\end{array}$ & $\begin{array}{l}\text { Foliage } \\
\text { Internal stem }\end{array}$ & $\begin{array}{l}\text { Density-dependent }{ }^{\mathrm{c}} \\
\text { Significant }\end{array}$ \\
\hline
\end{tabular}

${ }^{\text {a }}$ For accidentally introduced agents, date indicates earliest US record.

b Target host: *indicates host in native range but limited use in North America.

${ }^{c} M$. janthinus adult impact ranges from minimal to significant, depending on agent density.

d Impact unknown in US because establishment of agent unknown. 
Preliminary results discussed above suggest that experimental methods for detecting differential species-specific responses to herbivores in host plant primary and secondary metabolic functioning might be appropriately used to refine the initial screening process for identifying effective candidate agents. Increasing the complexity and duration of overseas evaluations of candidate agents, especially if realistic field conditions can be approximated, would improve the odds that truly efficacious agents would be selected. Repeated measurements of insect and vegetation parameters taken at the same spatially registered locations and over the span of multiple field seasons appropriately attribute weed reduction to biocontrol efficacy (Pauchard et al., 2003); otherwise observed decreases in toadflax abundance and percent cover can only speculatively be attributed to the work of a biocontrol agent (Darwent et al., 1975; McClay, 1995).

Mecinus heydeni, a close relative of the stem-mining weevil, $M$. janthinus, is currently being investigated for potential deployment against Linaria vulgaris (R. DeClerck-Floate, Agriculture and Agri-food Canada, Lethbridge Research Centre, personal communication). This development signals an end to what appeared to be a prevailing lottery approach to classical biological control of toadflax in North America. Although the mechanistic basis of $M$. janthinus' success in controlling Dalmatian toadflax remains unknown, its impact is obvious. By selecting a closely related agent that is host-specific to yellow toadflax as the next candidate for screening, researchers have made an active choice based on past success. This tactic, to evaluate an agent closely related to a species that has demonstrated superlative control efficacy against a related target weed, marks a clear deviation from the previous, seemingly random approach taken to foreign exploration for new toadflax biocontrol agents.

Weed biological control agents are too often deemed "safe" because a number of assumptions are made with regard to the target weed's genetic, phenotypic, and geographical range in native and invasive ecosystems. Retrospective analyses, by synthesizing and summarizing all available data associated with weed-specialist herbivore complexes, help to identify specific issues emerging in established biocontrol programs and improve future programs by providing a checklist of consistent patterns (Louda et al., 2003) in ecological risks posed by classical biological control.

\section{Acknowledgments}

The authors acknowledge the technical support of B. FitzGerald, K. Oliphant, C. Davis, H. Tolf, J. Dinkins, D. FitzGerald, K. Friedrichsen, V. Miranda, B.G. FitzGerald, and G. Peck, and sincerely appreciate the comments and suggestions from anonymous reviewers that significantly improved the manuscript. This work was supported by the USFS Rocky Mountain Research Station and the USDI Bureau of Land Management and Bureau of Indian Affairs.

\section{References}

Albach, D.C., Meudt, H.M., Oxelman, B., 2005. Piecing together the new Plantaginaceae. Am. J. Bot. 92, 297-315.

Alberta Agriculture. 1988. In: Guide to Crop Protection in Alberta, Part 2-Non-chemical Control. AGDEX 606-2. Alberta Agriculture, Edmonton, AB, p. 28.

Alborn, H.T., Turlings, T.C.J., Jones, T.H., Stenhagen, G., Loughrin, J.H., Tumlinson, J.H., 1997. An elicitor of plant volatiles from beet armyworm oral secretion. Science 276, 945-949.

Alex, J.F., 1962. The taxonomy, history and distribution of Linaria dalmatica. Can. J. Bot. 40, 295-307.

Arnett, A.E., Louda, S.M., 2002. Re-test of Rhinocyllus conicus host specificity, and the prediction of ecological risk in biological control. Biol. Conserv. 106, 251-257.

Arnold, R.M., 1981. Population dynamics and seed dispersal of Chaenorrhinum minus of railroad cinder ballast. Herb. Pop. Dyn. 106, 80-91.

Arnold, R.M., 1982. Pollination, predation and seed set in Linaria vulgaris (Scrophulariaceae). Am. Midl. Nat. 107, 360-369.

Arnold, R.M., 1991. Dwarf snapdragon - the railroad weed. Weed Technol. 5, 467-468.

Arntz, A.M., DeLucia, E.H., Jordan, N., 1998. Contribution of photosynthetic rate to growth and reproduction in Amaranthus hybridus. Oecologia 17, 323-330.

BONAP (Biota of North America Program)-Texas A\&M University Bioinformatics Working Group, 1996. Scrophulariaceae (the Figwort Family). Available from: http://www.csdl.tamu.edu/FLORA/bonapfams/bonxxscr.htm.

Baars, J.R. 2000. Emphasizing behavioural host-range: the key to resolving ambiguous host-specificity results on Lantana camara L. In: Spencer, N.R. (Ed.), Proceedings of the X International Symposium on Biological Control of Weeds, 4-14 July 1999, Montana State University, Bozeman, MT, pp. 887-896.

Barthell, J.F., Randall, J.M., Thorp, R.W., Wenner, A.M., 2001. Promotion of seed set in yellow star-thistle by honey bees: evidence of an invasive mutualism. Ecol. Appl. 11, 1870-1883.

Boland, W., Gabler, A., Gilbert, M., Feng, Z., 1998. Biosynthesis of $C_{11}$ and $\mathrm{C}_{16}$ homoterpenes in higher plants; stereochemistry of the $\mathrm{C}-\mathrm{C}$-bond cleavage reaction. Tetrahedron 54, 14725-14736.

Bruun, H.G., 1937. Genetical notes on Linaria, I-II. Hereditas 22, 395-401.

CDFA. 2005. Linaria genus. In: Encycloweedia: notes on identification, biology and management of plants defined as noxious weeds by California law. California Department of Food and Agriculture. Available from: http://www.cdfa.ca.gov/phpps/ipc/weedinfo/linaria.htm.

Caesar, A.J. 2000. Insect-pathogen synergisms are the foundation of weed biocontrol. In: Spencer, N.R. (Ed.), Proceedings of the X International Symposium on Biological Control of Weeds, 4-14 July 1999, Montana State University, Bozeman, MT, pp. 793-798.

Callaway, R.M., DeLuca, T.H., Belliveau, W.M., 1999. Biological-control herbivores may increase competitive ability of the noxious weed Centaurea maculosa. Ecology 80, 1196-1201.

Carney, V.A. 2003. Ecological Interactions of Biological Control Agent, Mecinus janthinus Germar, and its Target Host, Linaria dalmatica (L.) Mill. Master of Science Thesis, University of Lethbridge, Lethbridge, Alberta.

Chater, A.O., Valdes, B., Webb, D.A., 1972. 14. Linaria Miller. In: Tutin, T.G., Heywood, V.H., Burges, N.A., Moore, D.H., Valentine, D.H., Walters, S.M., Webb, D.A. (Eds.), Flora Europeae, Vol. 3. Cambridge, MA, pp. 226-236.

Chen, Y.H., Welter, S.C., 2003. Confused by domestication: incongruent behavioral responses of the sunflower moth, Homoeosoma electellum (Lepidoptera: Pyralidae) and its parasitoid, Dolichogenidea homoeosomae (Hymenoptera: Braconidae), towards wild and domesticated sunflowers. Biol. Control 28, 180-190.

Cock, M.J.W., 1978. The assessment of preference. J. Anim. Ecol. 47, 805-816.

Coombs, E.M., Clark, J.K., Piper, G.L., Cofrancesco, Jr., A.F. (Eds.), 2004. Biological Control of Invasive Plants in the United States. Oregon State University Press, Corvallis, OR. 
Craig, T.P., Itami, J.K., Abramson, W.G., Horner, J.D., 1993. Behavioral evidence for host-race formation in Eurosta solidaginis. Evolution 47, 1696-1710.

Craig, T.P., Itami, J.K., Shantz, C., Abrahamson, W.G., Horner, J.D., Craig, J.V., 2000. The influence of host plant variation and intraspecific competition on oviposition preference and offspring performance in the host races of Eurosta solidaginis. Ecol. Entomol. 25, 7-19.

Crawley, M.J., 1989. The successes and failures of weed biocontrol using insects. Biocontrol News Inf. 10, 213-223.

Darwent, A.L., Lobay, W., Yarish, W., Harris, P., 1975. Distribution and importance in northwestern Alberta of toadflax and its enemies. Can J. Plant Sci. 55, 157-162.

Davis, P.H. 1978. Flora of Turkey, vol. 6. Edinburgh University Press, Edinburgh, UK, pp. 654-672.

DeClerck-Floate, R.A., Harris, P., 2002. 72. Linaria dalmatica (L.) Miller, Dalmatian toadflax (Scrophulariaceae). In: Mason, P.G., Huber, J.T. (Eds.), Biological Control Programmes in Canada, 1981-2000. CABI, New York, NY, pp. 368-374.

DeClerck-Floate, R., Miller, V., 2002. Overwintering mortality of and host attack by the stem-boring weevil, Mecinus janthinus Germar, on Dalmatian toadflax (Linaria dalmatica (L.) Mill.) in western Canada. Biol. Control 24, 65-74.

Diehl, S.R., Bush, G.L., 1984. An evolutionary and applied perspective of insect biotypes. Annu. Rev. Entomol. 29, 471-504.

Docherty, Z., 1982. Self-incompatibility in Linaria. Heredity 49, 349-352.

Drès, M., Mallet, J., 2002. Host races in plant-feeding insects and their importance in sympatric speciation. Philos. Trans. R. Soc. Lond. B Biol. Sci. 357, 471-492.

Ellstrand, N.C., Schierenbeck, K.A., 2000. Hybridization as a stimulus for the evolution of invasiveness in plants? Proc. Natl. Acad. Sci. USA 97 7043-7050.

Follett, P.A., Duan, J.J., 2000. Nontarget Effects of Biological Control. Kluwer Academic Publishers, Boston, MD.

Futuyama, D.J. 1999. Potential evolution of host range in herbivorous insects. In: Van Driesche, R., Heard, T., McClay, A., Reardon, R. (Eds.), Host Specificity of Exotic Arthropod Biological Control Agents: the Biological Basis for Improvement in Safety, Proceedings of Session: X International Symposium on Biological Control of Weeds, July 4-14, 1999, Bozeman MT. US Forest Service Forest Health Technology Enterprise Team Publication FHTET-99-1. Morgantown, WV, pp. $42-53$.

Gaskin, J.F., Schaal, B.A., 2002. Hybrid tamarix widespread in U.S. invasion and undetected in native asian range. Proc. Natl. Acad. Sci. USA $99,11256-11259$.

Gassmann, A., 2001. Annual Report: Investigations on Potential Biological Control Agents of Dalmatian and Yellow Toadflax. CAB International, Delemont, Switzerland. $16 \mathrm{pp}$

Gassmann, A., Louda, S.M., 2001. Rhinocyllus conicus: initial evaluation and subsequent ecological impacts in North America. In: Wajnberg, E., Scott, J.K., Quimby, P.C. (Eds.), Evaluating Indirect Ecological Effects of Biological Control. CAB International, New York, NY, pp. 147-183.

Gassmann, A., Paetel, C. 1998. Summary report 1996-1998: Gymnetron netum (Col.: Curculionidae): a potential agent for biological control of toadflax in North America. International Institute of Biological Control, European Station, Delemont, Switzerland.

Goulson, D., Derwent, L.C., 2004. Synergistic interactions between an exotic honeybee and an exotic weed: pollination of lantana camara in australia. Weed Res. 44, 195-202.

Groppe, K. 1992. Final report: Gymnetron antirrhini Paykull (Col.: Curculionidae). A candidate for biological control of dalmatian toadflax in North America. International Institute of Biological Control, European Station, Delemont, Switzerland.

Grubb, R.T., Nowierski, R.M., Sheley, R.L., 2002. Effects of Brachypterolus pulicarius (L.) (Coleoptera: Nitidulidae) on growth and seed production of Dalmatian toadflax, Linaria gentisfolia ssp. dalmatica (L.) Maire and Petitmengin (Scrophulariaceae). Biol. Control 23, 107-114.

Hansen, R., Gassmann, A.2002. Utilization of North American Scrophulariaceae by Mecinus janthinus, a classical biological bontrol agent of the exotic weed Dalmatian toadflax, Linaria dalmatica. Poster presented at the 50th Annual Meeting of the Entomological Society of America, 17-20 November 2002, Fort Lauderdale, FL.

Harris, P., 1984. Linaria vulgaris Miller, yellow toadflax and L. dalmatica (L.) Mill., broad-leaved toadflax. In: Kelleher, J.S., Hulme, M.A. (Eds.), Biological Control Programmes Against Insects and Weeds in Canada, 1969-1980. CAB, Farmham Royal, UK, pp. 179-182.

Harris, P., 1961. Control of toadflax by Brachypterolus pulicarius (L.) (Coleoptera: Nitidulidae) and Gymnetron antirrhini (Payk.) (Coleoptera: Curculionidae) in Canada. Can. Entomol. 93, 977-981.

Harris, P., 1963. Host specificity of Calophasia lunula (Hufn.) (Lepidoptera: Noctuidae). Can Entomol. 95, 101-105.

Harris, P., Carder, A.C. 1971. Linaria vulgaris Miller, yellow toadflax and L. dalmatica (L.) Mill., broad-leaved toadflax. In: Biological Control Programmes Against Insects and Weeds in Canada, 1959-1968. Commonwealth Institute of Biological Control, Technical Communication No. 4, pp. 94-97.

Harris, P., McEvoy, P. 1995. The predictability of insect host plant utilization from feeding tests and suggested improvements for screening weed biological control agents. Delfosse, E.S., Scott, R.R. (Eds.). Proceedings of the Eighth International Symposium on Biological Control of Weeds, 2-7 February 1992, Lincoln University, Canterbury, New Zealand. DSIR/CSIRO, Melbourne, pp. 125-131.

Harris, P., Gassmann, A. 2004. Rhinusa (Gymnetron) antirrhini Paykull, $R$. neta Germar and Rhinusa sp. toadflax seed weevils. Available from: http://res2.agr.ca/lethbridge/weedbio/agents/arhiant_e.htm.

Harris, P., DeClerck-Floate, R. 2003. Lethbridge Research Centre-Biology of target weeds: broad- and narrow-leaved Dalmatian toadflax, Linaria dalmatica (L.) Mill., and L. gentisfolia (L.) Mill. Available from: http://res2.agr.gc.ca/lethbridge/weedbio/plant/bdaltoad_e.htm.

Hartl, D. 1974. 2. Auflage. In: Hartl, D., Wagenitz, G. (Eds.), Illustrierte Flora von Mitteleuropa. Bd. VI, 1. Teil. Carl Hanser Verlag, Munchen, pp. 73-94.

Heard, T. 1999. Concepts in insect host-plant selection behavior and their application to host specificity testing. In: Van Driesche, R., Heard, T., McClay, A., Reardon, R.(Eds.), Host Specificity of Exotic Arthropod Biological Control Agents: the Biological Basis for Improvement in Safety, Proceedings of Session: X International Symposium on Biological Control of Weeds, July 4-14, 1999, Bozeman MT. US Forest Service Forest Health Technology Enterprise Team Publication FHTET99-1. Morgantown WV, pp. 1-10.

Hering, K.L. 2002. Genetic and behavioral variability in the ovary-feeding nitidulid Brachypterolus pulicarius collected from Dalmatian and yellow toadflax. M.S. Thesis, Montana State University, Bozeman,115 pp.

Holsinger, K.E., 2000. Reproductive systems and evolution in vascular plants. Proc. Natl. Acad. Sci. USA 97, 7037-7042.

Honnay, O., Bossuyt, B., 2005. Prolonged clonal growth: escape route or route to extinction? Oikos $108,427-432$.

Hopper, K.R., 2001. Research needs concerning nontarget impacts of biological control introductions. In: Wajnberg, E., Scott, J.K., Quimby, P.C. (Eds.), Evaluating Indirect Ecological Effects of Biological Control. CAB International, New York, NY, pp. 39-56.

Hopper, K.R., Roush, R.T., Powell, W., 1993. Management of genetics of biological-control introductions. Annu. Rev. Entomol. 38, 27-51.

Howarth, F.G., 1991. Environmental impacts of classical biological control. Annual Rev. Entomol. 36, 485-509.

Howarth, F.G., 2000. Nontarget effects of biological control agents. In: Gurr, G., Wratten, S. (Eds.), Biological Control: Measures of Success. Kluwer Academic Publishers, Boston, MD, pp. 369-403.

ITIS. 2004. Integrated Taxonomic Information System. Available from: http://www.itis.usda.gov.

Janko, B., 1964. Variation-pattern investigations in natural Linaria populations. 1. Pollen examinations. Acta Bot. Acad. Sci. Hung. 10, 258-274.

Jeanneret, P., Schroeder, D., 1992. Biology and host specificity of Mecinus janthinus Germar (Col.: Curculionidae), a candidate for the biological control of yellow and Dalmatian toadflax, Linaria vulgaris (L.) Mill. and Linaria dalmatica (L.) Mill. (Scrophulariaceae) in North America. Biocontrol Sci. Technol. 2, 25-34. 
Jeanneret, P., Schroeder, D. 1991. Final report: Mecinus janthinus Germar (Col.: Curculionidae): a candidate for biological control of Dalmatian and yellow toadflax in North America. International Institute of Biological Control, European Station, Delemont, Switzerland.

Karny, M. 1963. The possibilities of Calophasia lunula Hufn. (Lep.: Noctuidae) in the biological control of toadflax, Linararia vulgaris Mill. CAB Technical Bulletin No. 3, CABI, Wallingford, UK.

Kessler, A., Baldwin, I.T., 2001. Defensive function of herbivore-induced plant volatile emissions in nature. Science 291, 2141-2144.

van Klinken, R.D. 2000. Host specificity testing: why do we do it and how can we do it better? In: van Driesche, R., Heard, T., Mcclay, A., Reardon, R. (Eds.), Proceedings: Host Specificity of Exotic Arthropod Biological Control Agents: The Biological Basis for Improvement in Safety. USDA Forest Service, Forest Health Technology Enterprise Team, Morgantown, WV, pp. 54-68.

Kluge, R.L. 2000. The future of biological control of weeds with insects: no more 'paranoia', no more 'honeymoon'. In: Spencer, N.L. (Ed.), Proceedings of the X International Symposium on Biological Control of Weeds 4-14 July 1999, Bozeman, MT, Montana State Univ., Bozeman, pp. 459-467.

Kock, T., 1966. Bionmische und okologische Untersuchungen zur Entomofauna an Linaria vulgaris Miller (Scrophulariaceae). Z. Angew. Entomol. 58, 195-251.

Lajeunesse, S.E., 1999. Dalmatian and yellow toadflax. In: Sheley, R.L., Petroff, J.K. (Eds.), Biology and Management of Noxious Rangeland Weeds. Oregon State University Press, Corvallis, OR, pp. 202-216.

Levin, R.A., Raguso, R.A., McDade, L.A., 2001. Fragrance chemistry and pollinator affinities in Nyctaginaceae. Phytochemistry 58, 429-440.

Louda, S.M., 1998. Ecology of interactions needed in biological control practice and policy. Bull. Br. Ecol. Soc. 29, 8-11.

Louda, S.M., 2000. Negative ecological effects of the musk thistle biological control agent, Rhinocyllus conicus. In: Foullett, P.A., Duan, J.J. (Eds.), Nontarget Effects of Biological Control. Kluwer Academic Publishers, Boston, pp. 215-243.

Louda, S.M., Kendall, D., Connor, J., Simberloff, D., 1997. Ecological effects of an insect introduced for the biological control of weeds. Science 277, 1088-1090.

Louda, S.M., Pemberton, R.W., Johnson, M.T., Follett, P.A., 2003. Nontarget effects - the Achilles' heel of biological control? Retrospective analyses to reduce risk associated with biocontrol introductions. Annu. Rev. Entomol. 48, 365-396.

Louda, S.M., Rand, T.A., Russell, F.L., Arnett, A.E., 2005. Assessment of ecological risks in weed biocontrol: input from retrospective ecological analyses. Biol. Control 35, 253-264.

Marohasy, J., 1998. The design and interpretation of host-specificity tests for weed biological control with particular reference to insect behaviour. Biocontrol News Inf. 19, 13-20.

Mason, P.G., Huber, J.T., 2002. Biological Control Programmes in Canada, 1981-2000. CAB International, Wallingford, UK.

Mauricio, R., Rausher, M.D., 1997. Experimental manipulation of putative selective agents provides evidence for the role of natural enemies in the evolution of plant defense. Evolution 51, 1435-1444.

McClay, A.S., 1992. Effects of Brachypterolus pulicarius (L.) (Coleoptera: Nitidulidae) on flowering and seed production of common toadflax. Can Entomol. 124, 631-636.

McClay, A.S. 1995. Beyond "before-and-after": experimental design and evaluation in classical weed biological control. In: Delfosse, E.S., Scott, R.R. (Eds.), Proceedings of the Eighth International Symposium on Biological Control of Weeds. 2-7 February 1992, Lincoln University, Canterbury, NZ. DSIR/CSIRO, Melbourne, Australia, pp. 213-219.

McClay, A.S., DeClerck-Floate, R.A., 2002. Linaria vulgaris Miller, yellow toadflax (Scrophulariaceae). In: Mason, P.G., Huber, J.T. (Eds.), Biological Control Programmes in Canada, 1981-2000. CABI, New York, pp. $375-382$.

McClay, A.S., Hughes, R.B., 1995. Effects of temperature on developmental rate, distribution, and establishment of Calophasia lunula (Lepidoptera: Noctuidae), a biocontrol agent for toadflax (Linaria spp.). Biol. Control 5, 368-377.
McConnell, J., Marutani, M., Muniappan, R. 1995. Insect-induced changes in Chromolaena oderata. In: Delfosse, E.S., Scott, R.R. (Eds.), Proceedings of the VIII International Symposium on Biological Control of Weeds. 2-7 February 1992, Lincoln University, Canterbury, NZ. DSIR/CSIRO, Melbourne, Australia, pp. 587-595.

McEvoy, P.B., Coombs, E.M., 1999. Biological control of plant invaders: regional patterns, field experiments, and structured population models. Ecol. Appl. 9, 387-401.

McEvoy, P.B., Coombs, E.M., 2000. Why things bite back: unintended consequences of weed biological control. In: Follett, P.A., Duan, J.J. (Eds.), Nontarget Effects of Biological Control. Kluwer Academic Publishers, Boston, pp. 167-194.

Meyer, G.A., 2000. Effects of insect feeding on growth and fitness of goldenrod (Solidago altissima). Recent Res. Develop. Entomol. 3, 29-41.

Meyer, G.A., 1993. A comparison of the impacts of leaf- and sap-feeding insects on growth and allocation of goldenrod. Ecology 74, 1101-1116.

Müller, H., 1989. Growth pattern of diploid and tetraploid spotted knapweed, Centaurea maculosa Lam. (Compositae), and effects of the root-mining moth Agapeta zoegana (L.) (Lep.: Cochylidae). Weed Res. 29, 103-111.

Müller-Schärer, H., Steinger, T., 2004. Predicting evolutionary change in invasive, exotic plants and its consequences for plant-herbivore interactions. In: Ehler, L.E., Sforza, R., Mateille, T. (Eds.), Genetics, Evolution and Biological Control. CAB International, Wallingford, UK, pp. $137-162$.

Murdock, W.W., 1969. Switching in general predators: experiments on predator specificity and stability of prey populations. Ecol. Monogr. $39,335-354$.

Myers, J.H., Bazely, D.R., 2003. Ecology and Control of Introduced Plants. Cambridge University Press, New York.

Nadeau, L., King, J.R., 1991. Seed dispersal and seedling establishment of Linaria vulgaris Mill. Can. J. Plant Sci. 71, 771-782.

Narang, S.K., Tabachnick, W.J., Faust, R.M., 1993. Complexities of population genetic structure and implications for biological control programs. In: Narang, S.K., Bartlett, A.C., Faust, R.M. (Eds.), Applications of Genetics to Arthropods of Biological Control Significance. CRC Press, Boca Raton, FL, pp. 19-52.

Nechols, J.R., Kauffman, W.C., Schaefer, P.W. 1992. Significance of host specificity in classical biological control. In: Kauffman, W.C., Nechols, J.E. (Eds.), Selection Criteria and Ecological Consequences of Importing Natural Enemies. Thomas Say Publications in Entomology: Proceedings, Entomological Society of America, Lanham, MD, pp. 41-52.

Nowierski, R.M. 1995. 82. Dalmatian toadflax. In: Nechols, J.R., Andres, L.A., Beardsley, J.W., Goeden, R.D., Jackson, C.G. (Eds.), Biological Control in the Western United States: Accomplishments and Benefits of Regional Research Project W-84, 1964-1989. University of California, Division of Agriculture and Natural Resouces Publication 3361, pp. 239-243.

Nowierski, R.M., 2004. Calophasia lunula. In: Coombs, E.M., Clark, J.K., Piper, G.L., Cofrancesco, Jr., A.F. (Eds.), Biological Control of Invasive Plants in the United States. Oregon State University, pp. 384-386.

Nowierski, R.M., Hennessey, R. 1995. Ecological assessment: field release of the exotic weevil, Gymnetron antirrhini (Coleoptera: Curculionidae), for biological control of Dalmatian toadflax, Linaria dalmatica (Scrophulariaceae). Reviewed by C.P. Schwalbe, USDA-APHIS-PPQ.

O'Hanlon, P.C., Peakall, R., Briese, D.T., 1999. Amplified fragment length polymorphism (AFLP) reveals introgression in weedy Onopordum thistles: hybridization and invasion. Mol. Ecol. 8, 1239-1246.

Olmstead, R.G., DePamphilis, C.W., Wolfe, A.D., Young, N.D., Elisons, W.J., Reeves, P.A., 2001. Disintegration of the Scrophulariaceae. Am. J. Bot. 88, 348-361.

Olsson, U., 1975. On the heredity transmission of microstructures of testa in reciprocal crosses between Linaria vulgaris and L. repens. Hereditas $79,251-254$.

Olsson, U., 1974. A biometric study of the pollen morphology of Linaria vulgaris (L.) Miller and L. repens (L.) Miller (Scrophulariaceae) and their hybrid progeny in $F_{1}$ and $F_{2}$ pgenerations. Grana 14, 92-99.

Olejniczak, P., 2003. Optimal allocation to vegetative and sexual reproduction in plants: the effect of ramet density. Evol. Ecol. 17, 265-275. 
Overholt, W.A., Ewe, S.M.L., Diaz, R., Morgan, E.C., Moeri, O.E., 2004. Feeding effects of Ischnodemus variegatus (Hemiptera: Blissidae) on photosynthesis and growth of Hymenachne amplexicaulis (Poaeceae). Florida Entomol. 87, 312-316.

Paré, P.W., Tumlinson, J.H., 1997. De novo biosynthesis of volatiles induced by insect herbivory in cotton plants. Plant Physiol. 114, 1161-1167.

Paré, P.W., Tumlinson, J.H., 1998. Cotton volatiles synthesized and released distal to the site of insect damage. Phytochemistry 47, 521-526.

Paré, P.W., Tumlinson, J.H., 1999. Plant volatiles as a defense against insect herbivores. Plant Physiol. 121, 325-332.

Paré, P.W., Alborn, H.T., Tumlinson, J.H., 1998. Concerted biosynthesis of an insect elicitor of plant volatiles. Proc. Natl. Acad. Sci. USA 95, 13971-13975.

Pauchard, A., Alaback, P.B., Edlund, E.G., 2003. Plant invasions in protected areas at multiple scales: Linaria vulgaris (Scrophulariaceae) in the West Yellowstone area. Western North Am. Nat. 63, 416-428.

Pearson, D.E., Callaway, R.M., 2003. Indirect effects of host-specific biological control agents. Trends Ecol. Evol. 18, 456-461.

Pemberton, R.W. 1985. Native plant considerations in the biological control of leafy spurge. In: Delfosse, E.S. (Ed.), Proceedings of the VI International Symposium for the Biological Control of Weeds, 19-25 August 1984, Vancouver, Canada; Ottawa, Agriculture Canada, pp. 365-390.

Peterson, R.K.D., Sing, S.E., Weaver, D.K. 2005. Differential physiological responses of Dalmatian toadflax, Linaria dalmatica (L.) Miller, to injury from two insect biological control agents: implications for decision-making in biological control. Environ. Entomol. 34, 899-905.

Rautiainen, P., Koivula, K., Hyvärinen, M., 2004. The effect of withingenet and between genet competition on sexual reproduction and vegetative spread in Potentilla anserine ssp. egedii. J. Ecol. 92, 505-511.

Rees, N.E., 1977. Impact of Rhinocyllus conicus on thistles in southwestern Montana. Environ. Entomol. 6, 839-842.

Robocker, W.C., Schirman, R., Zamora, B.A., 1972. Carbohydrate reserves in roots of Dalmatian toadflax. Weed Sci. 20, 212-214.

Röse, U.S.R., Manukian, A., Heath, R.R., Tumlinson, J.H., 1996. Volatile semiochemicals released from undamaged cotton leaves: a systemic response of living plants to caterpillar damage. Plant Physiol. 111, 487-495.

Rosenheim, J.A., Kaya, H.K., Ehler, L.E., Marois, J.J., Jaffee, B.A., 1995. Intraguild predation among biological-control agents: theory and evidence. Biol. Control 5, 303-335.

Saner, M.A., Müller-Schärer, H., 1994. Impact of root mining by Eteobalea spp. on clonal growth and sexual reproduction of common toadflax, Linaria vulgaris Mill. Weed Res. 34, 199-204.

Saner, M., Groppe, K., Harris, P. 1990. Final report: Eteobalea intermediella Riedl and E. serratella Treitschke (Lep., Cosmopterigidae), Two suitable agents for the biological control of yellow and Dalmatian toadflax in North America. International Institute of Biological Control, Delemont, Switzerland.

Saner, M.A, Clements, D.R., Hall, M.R., Doohan, D.J., Crompton, C.W., 1995. The biology of Canadian weeds. 105. Linaria vulgaris Mill. Can. J. Plant Sci. 75, 525-537.

Schaffner, U., 2001. Host range testing of insects for biological weed control: how can it be better interpreted? BioScience 51,951-959.

Schierenbeck, K.A., Mack, R.N., Sharitz, R.R., 1994. Effects of herbivory on growth and biomass allocation in native and introduced species of Lonicera. Ecology 75, 1661-1672.

Selleck, G.W., Alex, J.F., Coupland, R.T., Smith, J.M. 1957. The effect of Brachypterolus pulicarius on toadflax inflorescences. In: Research
Report of the National Weed Committee, Western Section, National Weed Committee, Canada. Department of Agriculture, Ottawa, p. 133. Simberloff, D., Stiling, P., 1996. How risky is biological control? Ecology 77, 1965-1974.

Singer, M.C., 2000. Reducing ambiguity in describing plant-insect interactions: preference, acceptability and electivity. Ecol. Lett. 3, 159-162.

Smith, J.M., 1956. Biological control of weeds in 1955. In: Vinoth, J. (Ed.), Proc. 9th National Weed Committee (Eastern sect.), National Weed Committee, Canada. Department of Agriculture, Ottawa, pp. 102-103.

Smith, J.M., 1959. Notes on insects, especially Gymnaetron spp. (Coleoptera: Curculionidae), associated with toadflax, Linaria vulgaris Mill. (Scrophulariaceae), in North America. Can. Entomol. 91, 116-121.

Sonder, L.W., Talbert, R.E., 1973. The status of Dalmatian toadflax in california. In: Proceedings-California Weed Conference. San Jose, CA. p p. 51-54.

Story, J.M., 1992. Biological control of weeds: selective, economical and safe. Western Wildlands 18, 18-23.

Strauss, S.Y., Agrawal, A.A., 1999. The ecology and evolution of plant tolerance to herbivory. Trends Ecol. Evol. 14, 179-185.

Sutton, D.A., 1988. A Revision of the Tribe Anthirrhineae. British Museum (Natural History). Oxford University Press, London.

Syrett, P., Briese, D.T., Hoffmann, J.H., 2000. Success in biological control of terrestrial weeds by arthropods. In: Gurr, G., Wratten, S. (Eds.), Biological Control: Measures of Success. Kluwer Academic Publishers, Netherlands, pp. 189-230.

Thelen, G.C., Vivanco, J.M., Newingham, B., Good, W., Bais, H.P., Landres, P., Caesar, A., Callaway, R.M., 2005. Insect herbivory stimulates allelopathic exudation by an invasive plant and the suppression of natives. Ecol. Lett. 8, 209-217.

Thomas, M.B., Willis, A.J., 1998. Biocontrol—risky but necessary? Trends Ecol. Evol. 13, 325-329.

Trumble, J.T., Kolodny-Hirsch, D.M., Ting, I.P., 1993. Plant compensation for arthropod herbivory. Annu. Rev. Entomol. 38, 93-119.

Turlings, T.C.J., Loughrin, J.H., McCall, P.J., Rose, U.S.R., Lewis, W.J., Tumlinson, J.H., 1995. How caterpillar-damaged plants protect themselves by attracting parasitic wasps. Proc. Natl. Acad. Sci. USA 92, 4169-4174.

Turner, C.E., Pemberton, R.W., Rosenthal, S.S., 1987. Host utilization of native Cirsium thistles (Asteraceae) by the introduced weevil Rhinocyllus conicus (Coleoptera: Curculionidae) in California. Environ. Entomol. 16, 111-115.

USDA-NRCS. 2004. The PLANTS Database, Version 3.5 (http:// plants.usda.gov). National Plant Data Center, Baton Rouge, LA 70874-4490, USA.

Wajnberg, E., Scott, J.K., Quimby, P.C. (Eds.), 2001. Evaluating Indirect Ecological Effects of Biological Control. CAB International, Wallingford, UK.

Volenberg, D.S., Krauth, S.J., 1996. First record of Pteromalus microps (Hymenoptera, Pteromalidae) in the New World. Entomol. News 107, 272-274.

Vujnovic, K., Wein, R.W., 1997. The biology of Canadian weeds. 106. Linaria dalmatica (L.) Mill. Can J. Plant Sci. 77, 483-491.

Widrlechner, M.P., 1982. Historical and phenological observations on the spread of Chaenorrhinum minus across North America. Can. J. Bot. 61, 179-186.

Withers, T.M., 1999. Examining the hierarchy threshold model in a nochoice feeding assay. Entomol. Exp. Appl. 91, 89-95.

Zwölfer, H., Harris, P., 1984. Biology and host specificity of Rhinocyllus conicus (Froel.) (Col.: Curculionidae). Z. Angew. Entomol. 97, 36-62. 